\title{
ANALYSIS OF THE MAINTENANCE WORK ORDER DATA IN EDUCATIONAL FACILITIES
}

Deniz Besiktepe Ph.D. Student ${ }^{1}$, Dr.Mehmet E.Ozbek, Ph.D. ${ }^{2}$ and Dr.Rebecca A.Atadero Ph.D.

denizbk@colostate.edu

${ }^{1}$ Department of Civil \& Environmental Engineering, ${ }^{2}$ Department of Construction Management

\section{PROBLEM STATEMENT}

- Aging buildings

- Insufficient funding of maintenance needs

- Constraints in condition assessment process

- Lack of visual inspection as part of the condition assessment process

- Need for maximizing facility performance, budget allocation and minimizing the negative impacts of failures

\section{BACKGROUND}

MAINTENANCE WORK ORDERS Includes information of the maintenance activities which may lead a preliminary understanding of buildings conditions.

MAINTENANCE ACTIVITIES Architectural, carpentry, electrical, HVAC, mechanical, plumbing, structural, etc.

LACK OF USE OF THE MAINTENANCE WORK ORDER DATA IN THE CONDITION ASSESSMENT PROCESS

\section{DATA COLLECTION}

\begin{tabular}{llcccc}
\hline Institutions & State & $\begin{array}{c}\text { GSF of } \\
\text { Buildings }\end{array}$ & $\begin{array}{c}\text { Total \# of Average Age } \\
\text { Buildings }\end{array}$ & $\begin{array}{c}\text { Time Interval } \\
\text { of Buildings } \\
\text { of Work } \\
\text { Orders }\end{array}$ \\
\hline State \#1 & Colorado & $4,076,953$ & 60 & 63 & $2009-2018$ \\
State \#2 & Colorado & $12,361,537$ & 748 & 43 & $2008-2017$ \\
State \#3 & Colorado & $8,186,982$ & 409 & 67 & $2013-2017$ \\
Private \#1 & Colorado & $3,567,470$ & 74 & 51 & $2012-2018$ \\
School District \#1 & Colorado & $3,979,365$ & 70 & 43 & $2011-2017$ \\
Private \#2 & Connecticut & $2,792,464$ & 310 & 105 & $2013-2017$
\end{tabular}

THE MAIN FOCUS OF THE ANALYSIS

Revealing any possible relations between:

- MAINTENANCE ACTIVITES and BUILDING AGES

- MAINTENANCE ACTIVITES and BUILDING TYPES The analysis of this study provides a preliminary understanding of these relations.

\section{METHODOLOGY AND RESULTS}

MAJORITY OF WORK ORDERS

\section{- ELECTRICAL}

- (Heating, Ventilation, and Air Conditioning) HVAC

- PLUMBING

The distribution of work orders for the maintenance activities was relatively estimated for each individual building using below equation.

$$
D w b_{i}=\frac{1}{N w} \sum_{i=1}^{n} N w b_{i}
$$

Dwb: The distribution of work orders for each maintenance activity at building $i$

Nw: The total number of work orders for each
maintenance activity maintenance activity

Nwb: The number of work orders for each maintenance activity at building $i$

MAINTENANCE ACTIVITES and BUILDING AGES

Higher(H): five percent and greater of total work orders $(>5 \%)$ Lower(L): one percent and less of total work orders $(<1 \%)$. Zero $(\mathrm{Z})$ : zero work orders $(=0)$

\begin{tabular}{|c|c|c|c|c|c|c|c|c|c|c|c|c|c|c|c|c|c|c|}
\hline \multirow{2}{*}{$\begin{array}{l}\text { Maintenance } \\
\text { Activity Type }\end{array}$} & \multicolumn{3}{|c|}{ State \#1 } & \multicolumn{3}{|c|}{ State \#2 } & \multicolumn{3}{|c|}{ State \#3 } & \multicolumn{3}{|c|}{ Private \#1 } & \multicolumn{3}{|c|}{$\begin{array}{c}\text { School } \\
\text { District \# }\end{array}$} & \multicolumn{3}{|c|}{ Private \#2 } \\
\hline & H & $\mathbf{L}$ & $\mathbf{Z}$ & $\mathbf{H}$ & $\mathbf{L}$ & $\mathbf{Z}$ & H & $\mathbf{L}$ & $\mathbf{Z}$ & \begin{tabular}{|l|}
$\mathbf{H}$ \\
\end{tabular} & $\mathbf{L}$ & 7 & $\mathbf{H}$ & $\mathbf{L}$ & $\mathbf{Z}$ & $\mathrm{H}$ & $\mathrm{L}$ & $\mathbf{Z}$ \\
\hline & 36 & 73 & 47 & 53 & 43 & 32 & 49 & 62 & 48 & 51 & 55 & 46 & 38 & 4 & & 3 & 108 & 64 \\
\hline IVAC & 37 & 77 & 44 & 50 & 47 & 34 & 28 & 63 & 52 & 51 & 51 & 53 & 38 & 47 & & 51 & 107 & 10 \\
\hline Imbing & 40 & 76 & 45 & 51 & 45 & 32 & 79 & 54 & 44 & 27 & 51 & 55 & 45 & 48 & & 41 & & 141 \\
\hline
\end{tabular}

The analysis does not show that the older buildings receive a higher number of work orders as might be expected.

The average age of the buildings in each cluster is more than the average age of $\mathbf{3 4 . 2}$ years provided on the Sightlines report (2017).

\begin{tabular}{cccc}
\hline Average Age & $\mathbf{H}$ & $\mathbf{L}$ & $\mathbf{Z}$ \\
\hline$<40$ & $33 \%$ & $0 \%$ & $20 \%$ \\
$40-60$ & $61 \%$ & $56 \%$ & $60 \%$ \\
$>60$ & $6 \%$ & $44 \%$ & $20 \%$
\end{tabular}

MAINTENANCE ACTIVITES and BUILDING TYPES

\begin{tabular}{|c|c|c|c|c|c|c|c|c|c|c|c|c|c|}
\hline \multirow{3}{*}{$\begin{array}{l}\text { Maintenance } \\
\text { Activity Type }\end{array}$} & \multicolumn{6}{|c|}{ H } & \multicolumn{3}{|c|}{$\begin{array}{c}\mathrm{L} \\
\end{array}$} & \multicolumn{4}{|c|}{$\underline{Z}$} \\
\hline & te & $\# 2(c$ & & Private & $\# 11^{c}(\mathrm{~s})$ & & $\# 2(\%$ & $\mathrm{P}_{1}$ & $\neq 1(\%)$ & te $\#$ t & $\# 2(\%)$ & Brivate & e\#1 \\
\hline & \begin{tabular}{|l|l|}
$\mathrm{C}$ & $\mathrm{O}$ \\
\end{tabular} & & $u_{1}$ & C & $\mathrm{R}$ & O1 & $\begin{array}{c}C \\
\end{array} \mid$\begin{tabular}{l|l|l|}
$R$ & 01 \\
\end{tabular} & 然 & & \begin{tabular}{l|l|l}
$\mathrm{C}$ & $\mathrm{O}$ \\
\end{tabular} & $\begin{array}{llll} & R & O L \\
\end{array}$ & $\mathrm{C}$ & \\
\hline & \begin{tabular}{|l|l|}
0 & 3 \\
\end{tabular} & 33 & 34 & 100] & 0 & & \begin{tabular}{l|l|l|l|}
7 & 21 & 12 & 60 \\
\end{tabular} & \begin{tabular}{|l|l|l|} 
& 7 & 9 \\
\end{tabular} & & \begin{tabular}{l|l|l}
0 & 14 \\
\end{tabular} & 5 & \begin{tabular}{l|l|}
0 & 1 \\
\end{tabular} & \begin{tabular}{|l|} 
\\
\end{tabular} \\
\hline & \begin{tabular}{|l|l|}
33 & 3 \\
\end{tabular} & $\begin{array}{ll}0 \\
\end{array}$ & 34 & \begin{tabular}{l|l|l}
100 & 0 \\
\end{tabular} & 0 & & \begin{tabular}{l|l|l|}
30 & 15 & 43 \\
\end{tabular} & 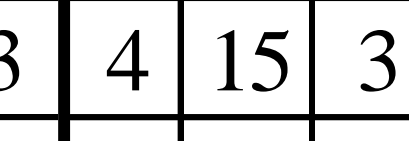 & & & \begin{tabular}{|l|l|}
6 & 84 \\
\end{tabular} & \begin{tabular}{l|l|}
0 & 0 \\
\end{tabular} & 0 \\
\hline
\end{tabular}

Classroom, office and research building types receive a higher number of work orders.

\section{CONCLUSIONS}

$\square$ THE HIGHEST NUMBER OF WORK ORDERS ARE:

- ELECTRICAL

- hVAC

- PLUMBING

$\square$ THE STUDY DOES NOT REVEAL A SPECIFIC RELATION BETWEEN:

- MAINTENANCE ACTIVITES and BUILDING AGES

- MAINTENANCE ACTIVITES and BUILDING TYPES

$\square$ THE STUDY PROVIDES A PRELIMINARY UNDERSTANDING OF:

- THE FREQUENT MAINTENANCE ACTIVITIES IN THE DATA SETS WITH THEIR RELATIONS OF BUILDING AGE AND BUILDING TYPE.

$\square$ THE DATA SETS NEED THE SUBCATEGORY* OF THE MAINTENANCE ACTIVITIES THAT:

- MAY INCREASE THE EFFECTIVE USE OF WORK ORDER DATA IN THE CONDITION ASSESSMENT PROCESS.

*Subcategories of the electrical maintenance activities can be light bulb changing, electrical panel issues, outlet/switch issues, etc. 